\title{
IMPLEMENTASI MODEL PEMBELAJARAN UCING SUMPUT UNTUK PEMBENTUKAN KARAKTER KEMANDIRIAN SISWA DALAM PEMBELAJARAN IPS
}

\author{
Sendi Fauzi Giwangsa ${ }^{1}$, Pupung Rahayu Novianti ${ }^{2}$ \\ STKIP Sebelas April Sumedang
}

\begin{abstract}
This research is motivated by the still low level of character development, especially independence in social studies learning. This is marked by the many problems of student independence such as cheating, not confident and always dependent on others. This is because social studies learning is synonymous with boring and unpleasant learning for students. Therefore, researchers conducted a research on the implementation of the grass suction model to instill the character of independence in social studies learning. The purpose of this study is to describe the planting of the character of independence by using the ucing sumput model in social studies learning. The subject of this study is the fifth grade students of SDN Pasirhuni. The method used in this study uses qualitative methods. Based on the results of the analysis, the use of the ucing sumput learning model can development the character of independence. This can be seen in the percentage of the emergence of independence indicators after using the ucing sumput model in social studies learning. The emergence of indicators of self-confidence reached $81 \%$, the emergence of indicators of self-employment reached $76 \%$ and the emergence of self-decision indicators reached $79 \%$. Thus it can be concluded that the ucing sumput learning model can shape the character of student independence.
\end{abstract}

Keyword: Ucing Sumput Model, Independence

\begin{abstract}
Abstrak: Penelitian ini dilatarbelakangi oleh masih rendahnya penanaman karakter dalam pembelajaran IPS. Hal ini ditandai dengan banyaknya permasalahan siswa seperti mencontek, tidak percaya diri dan kurang terlibat secara aktif dalam proses pembelajaran. Hal ini dikarenakan pembelajaran IPS identik dengan pembelajaran yang mebosankan dan tidak menyenangkan bagi siswa. Oleh karena itu peneliti melakukan penelitian implementasi model ucing sumput untuk menanamkan karakter kemandirian dalam pembelajaran IPS. Tujuan penelitian ini untuk mendeskripsikan penanaman karakter kemandirian dengan mengunakan model ucing sumput dalam pembelajaran IPS. Subjek penelitian ini yaitu siswa kelas V SDN Pasirhuni Metode yang digunakan dalam penelitian ini menggunakan metode kualitatif. Berdasarkan hasil analisis, penggunaan model pembelajaran ucing sumput dapat menanamkan karakter kemandirian. Hal ini dapat dilihat dalam persentase kemunculan indikator kemandirian setelah menggunakan model ucing sumput dalam pembelajaran IPS. Kemunculan indikator percaya diri mencapai $81 \%$, kemunculan indikator bekerja sendiri mencapai $76 \%$ dan kemunculan indikator mengambil keputusan sendiri mencapai 79\%. Dengan demikian dapat disimpulkan bahwa model pembelajaran ucing sumput dapat membentuk karakter kemandirian siswa.
\end{abstract}

Kata Kunci: Model Ucing Sumput, Kemandirian

\section{PENDAHULUAN}

Pendidikan merupakan salah satu usaha untuk dapat meningkatkan sumber daya manusia (SDM). Seperti yang tercantum dalam UU No 20 Tahun 2003 tentang Sstem Pendidikan Nasional menjabarkan bahwa tujuan pendidikan nasional yaitu untuk mengembangkan

ISTKIP Sebelas April Sumedang, Email: sendifauzigiwangsa国gmail.com

${ }_{2}^{2}$ STKIP Sebelas April Sumedang, Email: navianti.rahayu国yahou.com

148 EduHumaniora: Vol. 11 No. 2, Juli 2019 
kemampuan dan membentuk watak serta peradaban bangsa yang bermartabat dalam rangka mencerdaskan kehidupan bangsa, bertujuan untuk berkembangnya potensi peserta didik agar manjadi manusia yang beriman dan bertawa kepada Tuhan Yang Maha Esa, berakhlak mulia, sehat, berilmu, cakap, kreatif, mandiri dan menjadi warganegara yang demokratis serta bertanggung jawab. Berdasarkan kutipan tujuan pendidikan nasional tersebut bahwa pendidikan tidak hanya untuk membentuk siswa untuk menjadi cerdas dan berilmu namun juga memiliki watak serta akhlak yang mulia.

Hal ini sejalan dengan pendapat Lickona (2013) bahwa umumnya pendidikan memiliki tujuan besar yaitu membantu anak-anak menjadi pintar dan baik. Namun dalam prakteknya pendidikan khususnya pada pendidikan dasar cenderung lebih didominasi pada aspek pengetahuan untuk membuat siswa pintar, sedangkan aspek sikap cenderung menjadi lalai. Oleh karena itu akhir-akhir ini sedang digaungkan pendidikan karakter. Terdapat 18 karakter yang menjadi fokus untuk mencapai tujuan pendidikan nasional. Karakter yang menjadi fokus kajian dalam penelitian in yaitu karakter kemandirian. Hal ini karena berdasarkan informasi dari guru kelas di kelas V (lima) SDN Pasirhuni Kecamatan Cimanggung siswa belum sepenuhnya memiliki karakter kemandirian. Hal ini dilihat dari permasalahan yang muncul seperti siswa kurang percaya diri, sehingga selalu bertanya hal-hal yang sebenarnya sudah mereka ketahui. Sehingga siswa terlalu sering meminta arahan dari guru. Selain itu siswa pun sering menyontek pekerjaan orang lain ketika mengerjakan tugas atau ulangan. siswa belum bisa belajar secara mandiri, hal ini terlihat ketika siswa harus menunggu perintah dari guru untuk mengerjakan soal atau tugas. Apabila belajar berkelompok kebanyakan siswa hanya mengandalkan temannya untuk mengerjakannya. Fenomena tersebut menggambarkan bahwa kemandirian siswa belum berkembang secara optimal, sehingga apabila hal ini dibiarkan maka dapat berpengaruh terhadap perkembangan psikologis siswa yang bisa saja menjadi kurang percaya diri dan tidak bisa mengoptimalkan kemampuan yang dimilikinya dan yang lebih parah siswa akan tergantiung terhdap orang lain. Hal ini tidak sejalan dengan tujuan pendidikan secara psikologis yaitu untuk menjadi manusia yang dewasa yang tidak tergantung terhadap orang lain.

Berdasarkan uraian di atas maka peneliti melakukan penelitian yang berjudul "Implementasi Model Pembelajaran Ucing sumput Untuk Pembentukan Karakter Kemandirian Siswa Dalam Pembelajaran IPS”.

\section{TINJAUAN PUSTAKA}

Menurut Kamus Besar Bahasa Indonesia kemandirian yaitu keadaan dapat berdiri sendiri tanpa tergantung pada orang lain. Meskipun manusia sebagai mahluk sosial yang tidak bisa hidup sendiri, namun bukan berarti bahwa hidup harus secara terus menerus tergantung pada orang lain, hal ini karena terkadang ada beberapa hal yang harus bisa ditentukan oleh diri sendiri tanpa menghiraukan orang lain karena masnusia juga sebagai makhluk individu yang mana harus berani mengambil keputusan sendri yang dilandasi oleh pemahaman akan segala konsekuensi dari perbutannya (Suid, dkk, hlm. 2017). Hal ini sejaln dengan apa yang dikatakan Desmita (2009, hlm. 185) bahwa kemandirian merupakan kemampuan mengendalikan dan mengatur pikiran, perasaan dan perbuatan secara bebas serta berusaha sendri mengatasi keragu-raguan dan perasaan malu. Hal ini penting karena kemandirian akan menentukan bisa atau tidak seseorang dalam menghadapi permasalahan yang akan dihadapi.

Adapun ciri kemandirian (Gea, dkk., 2003; Desmita, 2009) diantaranya yaitu percaya diri, mampu bekerja sendiri, melaksanakan instruksi dengan baik, tanggung jawab, serta mampu mengambil 
keputusan sendiri. Hal ini sejalan dengan pendapat dari Pasani dan Pranita (2014) bahwa indikator dari kemandirian adalah sebagai berikut.

1. Melaksanakan instruksi dengan baik selama proses belajar.

2. Fokus, serius dan dapat konsisten selama pembelajaran berlangsung.

3. Memiliki kepercayaan diriatau keyakinan dalam menyelesaikan tugas yang diberikan.

4. Tidak mencontek atau meniru pekerjaan orang lain.

5. Mengerjakan atau menyelesaikan sendiri tugas dan latihan yang diberikan

Berdasarkan beberapa pendapat di atas maka rumusan indicator kemandirian yang dipakai dalam penelitian ini yaitu dari Suid, dkk (2017) adalah sebagai berikut.

Tabel 1. Indikator Karakter Kemandirian

\begin{tabular}{|c|c|}
\hline Indikator & Aspek yang diamati \\
\hline \multirow[t]{3}{*}{ Percaya diri } & Berani tampil di depan umum \\
\hline & $\begin{array}{l}\text { Berani bertanya atau } \\
\text { mengemukakan pendapat }\end{array}$ \\
\hline & $\begin{array}{l}\text { Yakin ketika mengerjakan } \\
\text { tugas }\end{array}$ \\
\hline \multirow[t]{3}{*}{$\begin{array}{l}\text { Mampu } \\
\text { bekerja sendiri }\end{array}$} & $\begin{array}{l}\text { Melakukan instruksi dengan } \\
\text { baik }\end{array}$ \\
\hline & $\begin{array}{l}\text { Menyelesaikan tugas secara } \\
\text { mandiri }\end{array}$ \\
\hline & $\begin{array}{l}\text { Tidak mencontek pekerjaan } \\
\text { orang lain }\end{array}$ \\
\hline \multirow{3}{*}{$\begin{array}{l}\text { Berani } \\
\text { mengambil } \\
\text { keputusan }\end{array}$} & $\begin{array}{l}\text { Mempu mengambil } \\
\text { keputusan sendiri }\end{array}$ \\
\hline & menyelesaikan \\
\hline & $\begin{array}{l}\text { Berani mengambil resiko atas } \\
\text { perbuatan sendiri }\end{array}$ \\
\hline
\end{tabular}

Ilmu Pengetahuan Sosial (IPS) merupakan salah satu mata pelajaran di Sekolah Dasar yang dalam pembelajarannya tidak hanya menekankan pada asapek kognitif namun juga penanaman karakter bagi anak. Namun pada prakteknya pembelajaran IPS seringkali hanya menekankan pada aspek kognitif, sehingga pembelajaran IPS terkesan membosankan karena terlalu banyak teori serta cara penyampaian teoriteori tersebut yang terlalu monoton sehingga pembelajaran dirasa kurang menyenangkan (Giwangsa, 2017). Untuk mengatasi permasalahan tersebut diperlukan model-model pembelajaran yang menyenagkan bagi siswa namun juga dapat dijadikan sarana untuk mengembangkan aspek pengetahuan, sikap serta keterampilan. Salah satu model yang bisa digunakan yaitu dengan menggunakan model permainan ucing sumput untuk meningkatkan karakter mandiri serta bisa memberikan pengalaman belajar yang lebih menyenangkan bagi siswa.

Model permainan ucing sumput ini merupakan hasil rekontruksi dari permainan tradisional ucing sumput yang dimodifikasi sehingga bisa digunakan sebagai model pembelajaran yang menyenangkan sekaligus juga sebagai sarana dalam menanamkan karakter mandiri. Model permaianan ucing sumput ini dipilih karena dalam model ini anak seolah sedang bermain namun dalam kegiatan bermain tersebut dapat dijadikan sarana untuk menananmkan karakter bagi anak khususnya karakter mandiri. Hal ini sejalan dengan hasil penelitian Satriana (2013) bahwa aktivitas bermain dapat menstimulasi perkembangan kogtnif, fisik serta afektif anak.

\section{METODOLOGI PENELITIAN}

Penelitian ini menggunakan metode penelitian kualitatif. Subjek penelitian ini adalah peserta didik kelas V SDN Pasirhuni Kecamatan Cimanggung Kabupaten Sumedang yang berjumlah 26 orang.

Adapun teknik pengumpulan data yang digunakan dalam penelitian ini yaitu dengan teknik tes dan teknik nontes. Teknik tes untuk melihat sejauh mana keberhasilan belajar siswa, sedangkan teknik nontes digunakan untuk mengukur sejauh mana kemunculan karakter kemandirian pada siswa ketika proses pembelajaran berlangsung.

Instrumen yang digunakan dalam penelitian ini yaitu dengan menggunakan 
lembar soal untuk mengukur keberhasilan belajar siswa dan instrumen pedoman observasi untuk melihat kemunculan karakter kemandirian ketika proses pembelajaran. Teknik analisis data menggunakan analisis deskriptif yaitu dengan menganalisis hasil belajar dan penanaman karakter dengan melihat persentase yang dicapai yang selanjutnya hasil persentase tersebut akan dideskripsikan.

\section{HASIL PENELITIAN DAN PEMBAHASAN}

Penelitian ini dimulai dengan menganalisis permainan-permainan tradisional di wilayah Sumedang, yang kemudian akan dipilih untuk dijadikan sebuah model pembelajaran. Salah satu permaianan yang memungkinkan direkontruksi menjadi sebuah model pembelajaran dalam pembelajran IPS adalah permainan Ucing sumput. Berikut tahapan permaian ucing sumput yang biasanya dimainkan oleh anak-anak (Kurniati: 2016).

1) Kumpulkan anak-anak sebanyakbanyaknya.

2) Untuk menentukan ucing, seluruh anak melakukan "hompimpah" atau "gambreng", sampai tersisa dua anak.

3) Kedua anak yang tersisa melakukan suit.

4) Anak yang kalah sulit menjadi ucing (kucing) atau jaga tempat.

5) Anak yang menjadi ucing harus menutup mata dan berhitung sampai hitungan 25 .

6) Anak yang lain (selain yang menjadi ucing) mencari tempat persembunyian

7) Jika sudah habis hitungan sampai 25 , anak yang jaga langsung mencari teman-temannya yang bersembunyi. Jika sudah ditemukan satu anak, ucing cepat-cepat balapan dengan anak yang telah ditemukan sampai ke tempat jaga. Kemudian pegang tempat jaga sambil teriak "Hong" tandanya satu orang telah ditemukan, tinggal mencari yang lainnya.

8) Kalau ternyata yang lebih dulu sampai tempat jaga adalah teman yang bersembunyi, permainan ronde pertama selesai dan yang jaga tempat dihukum harus jaga lagi pada permainan selanjutnya.

9) Ucing sumput biasanya dilakukan di lapangan atau halaman yang luas.

Permaianan tersebut kemudian direkontruksi dan disesuaikan dengan situasi kondisi di sekolah sehingga bisa digunakan sebagai model pembelajaran dalam pembelajran IPS. Berikut tahapan dari model permainan ucing sumput yang digunakan dalam pembelajaran IPS di kelas $\mathrm{V}$ pada materi kegiatan ekonomi sesuai letak geografis. Pembelajaran dimulai dengan tanya jawab kepada siswa mengenai materi yang akan diajarkan. Hal ini untuk melihat sejauh mana pemahaman awal siswa terhadap materi yang akan di ajarkan. Selanjutnya guru akan mengatur siswa untuk memulai permainan ucing sumput yang sudah direkontruksi. Berikut urutan permainan ucing sumput tersebut.

1) Jika dalam permainan Ucing sumput anak-anak dikumpulkan sebanyakbanyaknya, tetapi dalam model pembelajaran disesuaikan dengan jumlah anak di kelas.

2) Sebelum memulai permainan guru terlebih dahulu menjelaskan aturan dalam permainan ucing sumput.

3) Untuk menentukan ucing, seluruh anak melakukan "hompimpah" atau bermain cang kacang panjang, sampai tersisa dua anak.

4) Kedua anak yang tersisa melakukan suit.

5) Anak yang kalah suit menjadi ucing (kucing) atau jaga tempat dan anak yang menang menjadi pemain.

6) Ucing bertugas memegang selembar kertas yang berisi soal-soal pelajaran, sedangkan pemain masing-masing bertugas memegang sepatu miliknya masing-masing namun hanya sebelah. 
7) Anak yang menjadi ucing harus menutup mata dan berhitung sampai hitungan 25.

8) Anak yang lain (selain yang menjadi ucing) mencari tempat persembunyian, tetapi disini ada perbedaan, jika dalam permainan Ucing sumput yang bersembunyinya adalah para pemain, tetapi dalam model pembelajaran ini, yang bersembunyi adalah sepatu masingmasing pemain namun hanya sebelah saja yang digunakannya.

9) Ketika ucing menghitung sampai 25 , para pemain menyembunyikan sepatunya di sela-sela tempat diruangan kelas yang mereka anggap tempat paling aman agar tidak mudah ditemukan oleh ucing.

10) Jika sudah habis hitungan sampai 25 , ucing langsung mencari sepatu yang disembunyikan pemain. Jika sudah ditemukan, ucing akan kembali ketempat semula.

11) Setelah itu ucing menanyakan milik siapa sepatu yang telah ditemukan, setelah memastikan milik pemain yang mana, ucing melontarkan pertanyaan kepada pemain tersebut.

12) Pemain berkewajiban menjawab soal yang terdapat di lembar kertas yang dipegang oleh ucing, jika pemain menjawab soal dengan benar maka dia bisa melanjutkan permainan, namun jika dia menjawab soal dengan salah, maka dia akan bertukar posisi untuk menjadi ucing.

13) Permainan terus diulangi sesuai kesepakatan bersama.

14) Jika permainan Ucing sumput dilakukan dilapangan atau halaman, model pembelajaran ini dilakukan di kelas.

Setelah permainan selesai maka siswa kembali duduk di bangku masing-masing. Kemudian siswa diberikan soal evaluasi yang harus dijawab oleh masing-masing siswa. Guru dan siswa membahas soal evaluasi bersama-sama yang ditutup dengan kesimpulan dari proses pembelajran. Secara garis besar tahapan pembelajaran menggunakan model ucing sumput ini yaitu tahap eksplorasi, kemudian tahap permainan ucing sumput dan tahap konfirmasi.

Berdasarkan data yang diperoleh melalui observasi mengenai penanaman karakter kemandirian dapt dilihat dalam table berikut ini.

Tabel 2. Persentase Hasil Penanaman Karakter Kemandirian

\begin{tabular}{llll}
\hline No & $\begin{array}{l}\text { Indikator } \\
\text { Kemandirian }\end{array}$ & $\begin{array}{l}\text { Persentase } \\
\text { (\%) }\end{array}$ & Kriteria \\
\hline 1 & Percaya Diri & 81 & Baik \\
\hline 2 & $\begin{array}{l}\text { Mampu } \\
\text { Bekerja } \\
\text { Sendiri }\end{array}$ & 76 & Cukup \\
\hline 3 & $\begin{array}{l}\text { Berani } \\
\text { Mengambil } \\
\text { Keputusan }\end{array}$ & 79 & Cukup \\
& & & \\
\hline
\end{tabular}

Berdasarkan Tabel 2, dapat terlihat bahwa setiap indikator dari karkater kemandirian sudah muncul. Indikator percaya diri persentase kemunculannya mencapai $81 \%$ yang masuk dalam kategori baik. Hal ini menunjukan siswa mulai percaya diri baik ketika bertanya jawab, ketika bermain ucing sumput, serta ketika menjawab soal evaluasi. Selanjutnya pada indikator bekerja sendiri menunjukan kemunculan sebesar $76 \%$ yang termasuk dalam kategori cukup. Hal ini karena ketika bermain ucing sumput siswa harus berusaha sendiri untuk mencari sepatu yang disembunyikan temannya jika siswa bermain sebagai ucing, dan siswa yang sepatunya ditemukan oleh ucing harus berusaha menjawab soal yang diberikan ucing. Hal ini melatih siswa untuk tidak selalu tergantung pada orang lain. Karena dalam momen-momen tertentu keberhasilan siswa akan ditentukan oleh diri mereka sendiri tanpa tergantung terhadap orang lain. Pada Indikator mengambil keputusan sendiri menunjukan kemunculan sebesar $79 \%$ yang masuk dalam kategori cukup. Hal ini karena dalam permaianan ucing sumput siswa dilatih untuk bisa mengambil keputusan ketika 
siswa memilih tempat untuk menyembunyikan sepatu mereka masingmasing tanpa harus mengikuti persembunyian sepatu dari pemian lain. Hal ini dapat melatih siswa untuk mempunyai pendirian sendiri ketika mengambil keputusan sehingga mereka bisa bertanggungjawab terhadap keputusan yang telah dia ambil. Dalam permianan ucing sumput ini siswa akan bertanggung jawab atas keputusan mereka menyembunyikan sepatu mereka dan ketika sepatu mereka ditemukan maka siswa sendiri yang akan menanggung resikonya dengna harus menjawab pertanyaan yang diberikna oleh ucing.

Berdasarkan hasil penelitian tersebut dapat terlihat bahwa penggunaan model ucing sumput dalam pembelajaran IPS dapat menanamkan karakter kemandirian siswa. Hal ini karena model permainan ucing sumput dapat melatih siswa untuk percaya diri, bekerja sendiri dan belajar menambil keputusan sendiri. Hal ini sejalan dengan pendapat Satriana (2013) bahwa melalui Permainan tradisional siswa akan mendapatkan stimulasi yang positif bagi perkembangan anak. Dalam hal ini penggunaan model permaianan ucing sumput dapat menstimulasi karakter kemandirian siswa. Selain itu dengan model permainan ucing sumput ini juga membuat proses pembelajaran IPS mejadi lebih menyenangkan karena anak seolah sedang bermain namun didalamnya dapat melatih pengetahuan serta penanaman karakter yang positif bagi siswa. Hal ini penting untuk dapat merubah persepsi pembelajaran IPS yang kurang menarik minat siswa. Dengan penggunaan model pembelajaran yang bisa membuat siswa aktif serta menyenagkan bagi siswa diharapkan pembelajaran IPS dapat membuat siswa antusias. Oleh karena itu dapat dikatakan bahwa pembelajaran IPS melalui model permainan ucing sumput dapat menanamkan karakter kemandirian dan juga menyenangkan bagi siswa.

\section{KESIMPULAN}

Berdasarkan hasil penelitian dan pembahasan yang telah dilakukan, maka dapat disimpulkan bahwa model permainan ucing sumput dapat dijadikan salah satu model pembelajaran untuk menanamkan karakter kemandirian dalam pembelajaran IPS. Hal ini terlihat dari persentase kemunculan dari setiap aspek indikator karakter kemandirian (percaya diri, bekerja sendiri dan mengambil keputusan sendiri). Persentase kemunculan indikator percaya diri mencapai $81 \%$ yang termasuk dalam kategori baik. Selanjutnya indikator bekerja sendiri persentase kemunculannya mencapai $76 \%$ yang termasuk dalam kategori cukup. Sedangkan pada indikator mengambil keputusan sendiri persentase kemunculannya mencapai $79 \%$ yang termasuk dalam kategori cukup.

\section{DAFTAR PUSTAKA}

Desmita. (2009). Psikologi Perkembangan Peserta Didik. Bandung: PT. Remaja Rosdakarya

Gea, dkk. (2003). Character Building I Relasi dengan Diri Sendiri (Ed Revisi). JAkrta: PT Elex Media Komputindo.

Giwangsa, Sendi Fauzi. (2017). Upaya Peningkatan Aktivitas dan Hasil Belajar IPS Melalui Penggunaan Media Maket. Jurnal Lensa Pendas Volume 2 Nomor 2, September 2017. Hal 16-23.

Kurniati, Euis. (2013). Permainan Tradisonal dan Peranannya Dalam Mengembangkan Keterampilan Sosial Anak. Jakarta: Kencana.

Lickona, T. (2013). Pendidikan Karakter Panduan Lengkap Mendidik Siswa menjadi Pintar dan Baik (Ed. Litas S) Bandung: Nusa Media

Pasani dan Pramita. (2014). Meningkatkan Karakter Mandiri dan Hasil BelajarMatematika Siswa Melalui Model Pembelajran Kooperatif Tipe Think Pair Share (TPS) di 
Kelas VIII-C SMPN 13

Banjarmasin. Jurnal Pendidikan

Matematika IAIN Antasari Vol.01

No. 2 Januari - Juni2014. Hal 17-

32

Satriana, Malpaeni. (2013). Permainan

Tradisional Berbasis Budaya

Sunda Sebagai Sarana Stimulasi

Perkembangan Anak Usia Dini.

Jurnal Pendidikan Usia Dini

Volume 7, Edisi 1 April 2013 Hal.

65-84

Suid, dkk. (2017). Analisis Kemandirian Siswa dalam Proses Pembelajaran di Kelas III SD Negeri I Banda Aceh. Jurnal Pesona Dasar Universitas Syah Kuala Vol. 1 No. 5, April 2017. Hal 70-81.

Undang-undang Nomor 20 Tahun 2003

Tentang Sistem Pendidikan Nasional. Jakarta: Kemristekdikti. [Online]Tersedia:

https://kelembagaan.ristekdikti.go .id/wp-

content/uploads/2016/08/UU_no_ 20_th_2003.pdf 